\title{
Use of Plasmapheresis: Acute Pancreatitis Due to Hypertriglyceridemia: Case Report
}

\section{Danny Fernado Silva Cevallos*, Diana Evangelista Barragan, Mirella Barrera Rivera, Casar Arreaga Perez, Angelica Zarate Zapata and Fernando Silva Michalon}

Department of Emergency/Internal Medicine, Guayaquil Clinical Hospital, Ecuador

*Corresponding Author: Danny Fernado Silva Cevallos, Department of Emergency/ Internal Medicine, Guayaquil Clinical Hospital, Ecuador.
Received: August 31, 2021

Published: September 20, 2021

(C) All rights are reserved by Danny Fernado Silva Cevallos., et al.

\begin{abstract}
Hypertriglyceridemic pancreatitis (PATG) is described as an uncommon cause with an incidence that ranges from 2 to $4 \%$ of cases, generates significant morbidity and mortality between 40 per 100,000 inhabitants in a western population [1,2]. There are several pathophysiological mechanisms that explain the appearance of pancreatitis caused by hypertriglyceridemia, one of them is the direct toxic role of free fatty acids on pancreatic tissue and another widely accepted mechanism is chylomicron-mediated vascular obstruction, given the decrease in the gene expression of lipoprotein lipase (LPL) [3]. The American Society for Apheresis (ASFA) indicates the use of plamapheresis when there is severe pancreatitis, when triglyceride levels exceed more than $2000 \mathrm{mg} / \mathrm{dl}$ and when there is no satisfactory response to first-line treatment; the success of the treatment is based on a decrease in triglycerides below $500 \mathrm{mg} /$ $\mathrm{dl}$ to achieve the goal of using plasmapheresis [4]. In this case, it was demonstrated that the timely assessment of the patient was essential to make treatment decisions in the appropriate time with a favorable response to it.
\end{abstract}

Keywords: Acute Pancreatitis, Hypertriglyceridemia, Plasmapheresis, Triglycerides

\section{Introduction}

Pancreatitis is described as an inflammatory process that affects the gland; Among the most common causes are those induced by gallstones as the main cause and alcohol abuse, leaving hypertriglyceridemic pancreatitis as an uncommon cause with an incidence that ranges from 2 to $4 \%$ of cases, generating significant morbidity and mortality. between 40 per 100,000 in the western population [1,2]. Studies have been carried out to establish the cutoff of triglycerides that can cause acute pancreatitis, although it is still unknown exactly, levels of greater than $1000 \mathrm{mg} / \mathrm{dl}$ have been established.
Although the pathophysiology is not clearly established, it is indicated that it is the result of several interactions with multiple factors, the accepted theory being excessive metabolism by pancreatic lipase and free fatty acids together with hyperviscosity due to excess triglycerides in the pancreatic capillaries that can cause ischemia [3,5]. It is associated with genetic disorders such as familial hypertriglyceridemia due to elevated ApoB and non-HDL cholesterol [6] due to lipoprotein lipase, which is an enzyme that hydrolyzes triglycerides into lipoproteins and plays an important role in triglyceride synthesis [7].

There are local complications such as necrosis, abscesses, pseudocyst and ascites, as well as systemic complications that start from 
gastrointestinal bleeding, hyperglycemia, hypercalcemia, diabetic ketoacidosis and acute respiratory distress syndrome, multiorgan dysfunction, disseminated intravascular coagulation and compartment syndrome [4].

Plasmapheresis is the method in which the plasma is disintegrated from the blood to purify it and, after the procedure, infuse the cleared plasma into the patient [8]. Plasmapheresis is used as a treatment option since it rapidly eliminates triglycerides and chylomicrons from the circulation, stopping the factor that triggers the clinical picture, the additional inflammation and pancreatic damage that it can produce compared to conservative treatment that takes days for its action. this treatment has been proposed especially in critically ill patients [1].

Currently the guidelines do not determine first-line therapies to act against this disease whose cause to be treated is hypertriglyceridemia, among the available options we have oral lipid-lowering drugs, insulin therapy, heparin and plasmapheresis [3]. The American Society for Apheresis (ASFA) indicates the use of plasmapheresis when there is severe pancreatitis when triglyceride levels exceed more than $2000 \mathrm{mg} / \mathrm{dl}$ and when there is no satisfactory response to first-line treatment; It has been evidenced between 46 to $80 \%$ reduction of symptoms with 2 to 3 sessions of plasmapheresis $[9,10]$. There are contraindications for the use of plasmapheresis such as mental disorders, circulatory failure, unstable cardiac or cerebral infarction, intracranial hemorrhage or severe cerebral edema and more than $72 \mathrm{~h}$ from the beginning of PATG.

\section{Description of the Clinical Case}

A 32-year-old female patient with a personal medical history: diabetes mellitus II, treated with Glimepiride/Metformin 2/850 mg per day. Hypertension diagnosed in February 2018, uncontrolled. Patient is admitted with clinical symptoms of approximately 8 hours of evolution, prior to admission, characterized by abdominal pain in the left upper quadrant with dorsal radiation in the hemicbelt, of great intensity 8/10, which does not subside with analgesia and is accompanied by nausea that they progress to vomiting on 3 occasions of nutritional content preceded by excessive intake of copious and high-fat food. On physical examination, dry mucous membranes, depressible soft abdomen, painful on deep palpation, hemicbelt pain, increased air-fluid noises, a nasogastric tube is placed where bilious discharge is evidenced. Hemodynamically sta- ble with vital signs BP 134/74 mmHg, HR 89 bpm, RR 19 rpm, Sat $98 \%$ room air, glycemia $333 \mathrm{mg} / \mathrm{dl}$. According to the clinical picture and complementary tests (Table 1 ), acute pancreatitis induced by Hypertriglyceridemia is determined as a diagnostic impression and is staged with the following scores: APACHE score 15 MORTALITY 30.4\%, MARSHALL: 1, BISAP: 1, RAMSAY: 5, RAMSON: 8 and by Tomographic study Baltasar: B.

\begin{tabular}{|c|c|}
\hline Blood profile & $\begin{array}{c}\text { Leukocytes } 12.88 \text { x103ul granulocytes } 76 \% \\
\text { lymphocytes } 16 \% \text { hemoglobin } 28.1 \mathrm{~g} / \mathrm{dl} \\
\text { Hcto. } 32.4 \% \text { platelets } 361 \times 103 \mathrm{Ul} . \\
\text { Evidence shows lipemic. }\end{array}$ \\
\hline Liver profile & $\begin{array}{c}\text { TG0 } 60.0 \mathrm{U} / \mathrm{l} \text { TGP } 45.0 \mathrm{U} / \mathrm{L} \text {, Bilirubin total } \\
19.30 \mathrm{mg} / \mathrm{dl} \text {, direct bilirubin } 15.60 \mathrm{mg} / \mathrm{dl} \\
\text { Amylase } 890 \mathrm{U} / \mathrm{l} \text { Lipase } 1080 \mathrm{U} / \mathrm{l} .\end{array}$ \\
\hline \multirow[t]{2}{*}{ Renal profile } & Urea $18.60 \mathrm{mg} / \mathrm{dl}$. Creatinine 0,60 mg/dl. \\
\hline & $\begin{array}{c}\text { PCR } 198,10 \mathrm{mg} / \mathrm{l} \text { Dehydrogenase Lactate } \\
1.560,0 \mathrm{u} / \mathrm{l}\end{array}$ \\
\hline Electrolytes & $\begin{array}{c}\mathrm{Na} 142.7 \mathrm{mmol} / \mathrm{l} \mathrm{K} 5.40 \mathrm{mmol} / \mathrm{l} \mathrm{Cl} .116 .9 \\
\mathrm{mmol} / \mathrm{L} \mathrm{Ca} .6 .90 \mathrm{mmol} / \mathrm{l} .\end{array}$ \\
\hline Arterial blood gases & $\begin{array}{c}\mathrm{Ph} 7,0 \mathrm{PCO}_{2} 11.7 \mathrm{Po}_{2} 154.5 \mathrm{HCO}_{3} 5.9 \mathrm{mmol} / \mathrm{l} \\
\mathrm{BE}-24,5 \mathrm{mmol} / \mathrm{L} \text { sat } 97.7 \%\end{array}$ \\
\hline Lipid Profile & $\begin{array}{c}\text { Cholesterol Total 1.270,0 mg/dl. HDL } 285.0 \\
\text { mg/dl. LDL } 431 \mathrm{mg} / \mathrm{dl} . \\
\text { Triglycerides } 7,080.0 \mathrm{mg} / \mathrm{dl} .\end{array}$ \\
\hline $\begin{array}{l}\text { Total Abdomen } \\
\text { Ultrasound }\end{array}$ & $\begin{array}{c}\text { Moderate fatty liver disease, acute } \\
\text { pancreatitis, peripancreatic fluid, } \\
\text { splenomegaly, aerocolia. }\end{array}$ \\
\hline $\begin{array}{l}\text { CT scan of the } \\
\text { abdomen and } \\
\text { simple pelvis }\end{array}$ & $\begin{array}{c}\text { Acute pancreatitis, splenomegaly, fatty liver } \\
\text { disease, follicles in ovaries. }\end{array}$ \\
\hline
\end{tabular}

Table 1: Entrance exams.

The critical medicine service is consulted because the patient, during the first hours of hospitalization, shows great intensity pain in the abdominal region 10/10, generalized paleness, tachycardia, heart rate 140 , with neurological deterioration, evidence in gasometric examination metabolic acidosis, we proceed to orotracheal intubation, with the following ventilatory parameters: Ventilatory mechanical ventilation: VCV, Total volume: $500 \mathrm{cc}$, PEEP: 6, FIO 60\%, RF: 18. 
Extensive hydration, insulin infusion, and analgesia are started are obvious results. Plasmapheresis is indicated as adjunctive therapy to the clinical picture using a high-flow vascular catheter. Duration of the procedure: 3 hours; 3,600 ml of milky plasma are extracted and the procedure is repeated after 24 hours. Duration 3 hours, obtaining $4000 \mathrm{ml}$ of lipemic plasma. It was decided to perform plasmapheresis where a lipemic sample was extracted (Illustration 1) with triglycerides of $7080 \mathrm{mg} / \mathrm{dl}$, achieving a $50 \%$ decrease in the first session and 2 more sessions were carried out, achieving a final result of triglycerides of $406 \mathrm{mg} / \mathrm{dl}$ (Table 2). According to clinical evolutionary pase and laboratory plasmapheresis in this patient were effective, reaching triglyceride values at the desired objectives, an appropriate neurological window was performed with spontaneous eye opening without being able to progress from mechanical ventilation due to high use of vasopressor, tachycardia, bilateral pulmonary infiltrates, metabolic acidosis, having to maintain mechanical ventilation, restart sedation, evolving unfavorably because he presented septic shock of pulmonary origin, bacteria were isolated in tracheal aspirate (Table 3), it was accompanied by hemorrhage and cerebral edema, leading to fatal death on the ninth day of hospitalization.

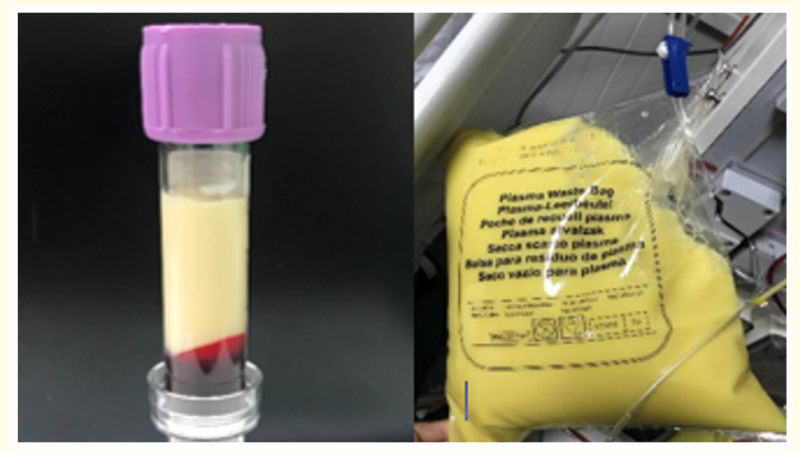

Illustration 1: Plasma lipemic sample.

\section{Discussion}

Mortality in Pancreatitis secondary to Hypertriglyceridemia varies from 2 to $4 \%$ of the cases registered in the literature, higher than other etiologies of acute pancreatitis: triglycerides can be elevated in mild or moderate pancreatitis of any etiology, however, its elevation it is $<500 \mathrm{mg} / \mathrm{dl}$ not comparable with hypertriglyceride-

\begin{tabular}{|l|c|}
\hline $\begin{array}{l}\text { First session of } \\
\text { Plasmapheresis }\end{array}$ & $\begin{array}{c}\text { Cholesterol total 620.0 mg/dl. HDL 37.7 } \\
\mathrm{mg} / \mathrm{dl} . \mathrm{LDL} 26.0 \mathrm{mg} / \mathrm{dl} \text {. Triglycerides } \\
3.040 .0 \mathrm{mg} / \mathrm{dl} \text {. Amylase 577.0 U/l Lipase } \\
388 \mathrm{U} / \mathrm{l} .\end{array}$ \\
\hline $\begin{array}{l}\text { Second session of } \\
\text { Plasmapheresis }\end{array}$ & $\begin{array}{c}\text { Total cholesterol } 569 \mathrm{mg} / \mathrm{dl} \text {. Triglycerides } \\
1700 \mathrm{mg} / \mathrm{dl} \text {. Amylase } 101.0 \mathrm{U} / \mathrm{l} \text { Lipase } 80 \\
\mathrm{U} / \mathrm{l} .\end{array}$ \\
\hline $\begin{array}{l}\text { Third session of } \\
\text { Plasmapheresis }\end{array}$ & $\begin{array}{c}\text { Triglycerides: } 406.0 \mathrm{mg} / \mathrm{dl} . \text { Amylase: } 54 \\
\mathrm{u} / \mathrm{l}, \text { Lipase } 48 \mathrm{u} / \mathrm{l}\end{array}$ \\
\hline
\end{tabular}

Table 2: Lipid profile after plasmapheresis session.

\begin{tabular}{|l|c|}
\hline Gram stain & $\begin{array}{c}\text { Coconut bacillus gram negative } \\
\text { polymorphonuclear4 - 6 x field }\end{array}$ \\
\hline Counting & X108 cfu/ml \\
\hline $\begin{array}{l}\text { Isolated Germ } \\
\text { Interpretation }\end{array}$ & $\begin{array}{c}\text { Acinetobacter baumannii } \\
\text { multirresistant }\end{array}$ \\
\hline Mayor $=105 \mathrm{ufc} / \mathrm{ml}$ & Infection \\
\hline Minor $=104 \mathrm{cfu} / \mathrm{ml}$ & Colonization \\
\hline
\end{tabular}

Table 3: Tracheal aspirate skin report.

mic pancreatitis in which the level will be $>1000 \mathrm{mg} / \mathrm{dl}$. Plasmapheresis has shown a reduction in mortality when used between the first 24 to 48 hours, lowering triglyceride values in the first session to normal levels or close to ranges between 50 and $80 \%$ of cases. According to the Apheresis Society and the American Medical Association, it is an indication III for therapeutic plasma exchange; Plasmapheresis therapy was used in the case described, determining very effective due to the decrease in triglycerides in the least possible time to correct the pathophysiological cascade. The results obtained in the case described with this technique were positive and its effectiveness was determined by the evident clinical improvement and decrease in triglyceride levels. It should be mentioned that this type of procedure is often not feasible due to the cost or because the hospital center does not have this procedure, however, when it is available, it is advisable to use it to lower triglyceride values, improve the patient's symptoms and thereby reducing mortality, which despite being low constitutes a serious complication. 


\section{Conclusion}

It can be concluded that plasmapheresis in these patients with severe hypertriglyceridemia is an effective treatment to reduce the risk of developing complications and mortality, taking into account the indications of the procedure and time of the therapy that should be performed at intervals of 24 to 48 hours, evaluating from upon admission, the possibility of performing the technique without delay, with this, it is intended to reduce complications and thus mortality.

\section{Recommendations}

The exhaustive evaluation of the patient with a history or with a clinical picture compatible with the disease is the fundamental pillar for making treatment decisions that have a special influence on these critical patients, thus reducing complications, morbidity and mortality.

\section{Thanks}

We thank the team that works within the institution and all those who helped make this publication possible.

\section{Bibliography}

1. Joglekar K., et al. "Therapeutic plasmapheresis for hypertriglyceridemia-associated acute pancreatitis: case series and review of the literature". Therapeutic Advances in Endocrinology and Metabolism 8.4 (2017): 59-65.

2. Sánchez RAMR., et al. "Utilidad de la plasmaféresis en la pancreatitis aguda por hipertrigliceridemia". Revista colombiana de Gastroenterología 35.2 (2020): 226-231.

3. Garg R and Rustagi T. "Management of Hypertriglyceridemia Induced Acute Pancreatitis”. BioMed Research International Hindawi (2018).

4. Marín-Sánchez JA., et al. "Pancreatitis aguda severa por hipertrigliceridemia en el adulto: Presentación de caso clínico, diagnóstico y tratamiento". Revista colombiana de Gastroenterología 33.4 (2018): 459-463.

5. Severe Hypertriglyceridemia-Related Acute Pancreatitis - Stefanutti - 2013 - Therapeutic Apheresis and Dialysis - Wiley Online Library (2013).
6. Herrera Del Águila DD., et al. "Pancreatitis aguda por hipertrigliceridemia severa: reporte de caso y revisión de la literature". Revista de Gastroenterología del Perú 35.2 (2015): 159164.

7. Rawla P., et al. "Hypertriglyceridemia-induced pancreatitis: updated review of current treatment and preventive strategies". Clinical Journal of Gastroenterology 11.6 (2018): 441448.

8. Senosiain Lalastra C., et al. "Pancreatitis aguda por hipertrigliceridemia". Clinical Gastroenterology and Hepatology 36.4 (2013): 274-279.

9. Izquierdo-Ortiz MJ and Abaigar-Luquin P. "Hipertrigliceridemia severa: Tratamiento con plasmaféresis". Nefrol Madr. 32.3 (2012): 417-418.

10. Song X., et al. "Intensive insulin therapy versus plasmapheresis in the management of hypertriglyceridemia-induced acute pancreatitis (Bi-TPAI trial): study protocol for a randomized controlled trial". Trials 20.1 (2019): 365.

11. Montaño-Padilla GS., et al. "The usefulness of plamapheresis in acute pancreatitis due to hypertriglyceridemia: A case report". Revista colombiana de Gastroenterología 35.2 (2020): 226-231.

\section{Volume 4 Issue 10 October 2021 \\ (C) All rights are reserved by Danny Fernado Silva Cevallos., et al.}

